\title{
Klasifikasi Mutu Buah Pala (Myristica Fragrans Houtt) Berbasis Pengolahan Citra Menggunakan Metode Deep Learning Arsitektur Faster R-CNN
}

\author{
Muh. Subhan ${ }^{1, a}$ Hasan Basri ${ }^{2}$ \\ ${ }^{1,2}$ Program Studi Manajemen Informatika, Politeknik Negeri Fakfak, (Jl.Imam Bonjol Atas, Air Merah-Wagom), Fakfak, \\ Papua Barat \\ asubhan@polinef.id
}

\begin{abstract}
Fakfak is the number one nutmeg producing area in Indonesia with a land area of around 16,011 Ha. Nutmeg production is projected to continue to increase until $\mathbf{2 0 2 0}$, recorded in 2011 the production of nutmeg in particular reached 12,884 tons or 25 percent of the total Indonesian nutmeg production. This increase was not followed by an increase in market share. One solution to get a wider nutmeg market is exports. But currently not all requests for nutmeg can be fulfilled, because the quality of the nutmeg does not meet the requirements requested. One factor is the surface defects in the nutmeg skin that affects the quality of the fruit, especially the appearance of the fruit. The sorting of nutmegs has so far been using conservative methods, namely by observation based on experience (self-taught). This manual method is felt to be less effective because it depends on the conditions and conditions of the sorting staff, different perceptions between each sorter, takes a long time, requires large costs and involves many workers. To deal with these problems, our previous research developed a method for classifying nutmeg seeds, using image processing methods with color and shape parameters combined with a neural network and sigmoid convolution classification algorithm as a validation method, an accuracy of $87 \%$, but this has not been said to be optimal so we try to use the same approach with the latest method improvements using the R-CNN Faster obtained the best accuracy of $95 \%$ with a learning rate of 4000 with a processing time of 0.04 minutes per second.
\end{abstract}

Keywords : pala; image processing; deep learning; Faster $R$ CNN; FRCNN;

Abstrak - fakfak adalah daerah penghasil pala nomor satu di indonesia dengan luas lahan sekitar 16.011 Ha. Produksi pala diproyeksikan terus meningkat sampai tahun 2020, tercatat pada tahun 2011 produksi pala fakfak khususnya mencapai 12.884 ton atau 25 persen dari total produksi pala indonesia. Peningkatan tersebut tidak diikuti dengan bertambahnya pangsa pasar. Salah satu solusi untuk mendapatkan pasar pala yang lebih luas adalah ekspor. Namun saat ini belum semua permintaan buah pala dapat terpenuhi, dikarenakan mutu pala kurang memenuhi persyaratan yang diminta. Salah satu faktornya adalah adalah cacat permukaan pada kulit buah pala sehingga mempengaruhi kualitas buah khususnya penampakan buah. Sortasi buah pala selama ini masih menggunakan cara konservatifl yaitu dengan pengamatan berdasar pengalaman (otodidak). Cara manual ini dirasa kurang efektif karena bergantung pada keadaan dan kondisi dari tenaga penyortir, perbedaan persepsi antara masing-masing penyortir, membutuhkan waktu lama, membutuhkan biaya yang besar dan melibatkan banyak pekerja. Untuk menangani permasalahan tersebut Penelitian sebelumnya kami mengembangkan metode untuk mengklasifikasikan biji buah pala, dengan menggunakan metode pengolahan citra dengan parameter warna dan bentuk dipadukan dengan algoritma klasifikasi konvolusi jaringan syaraf dan sigmoid sebagai metode validasinya didapatkan akurasi sebesar $87 \%$ namun hal ini belum dikatakan optimal sehingga kami mencoba menggunakan pendekatan yang sama dengan perbaikan metode terbaru menggunakan Faster R-CNN didapatkan akurasi terbaik sebesar $95 \%$ dengan learning rate 4000 dengan waktu proses 0.04 menit per detik.

Kata Kunci: pala, pengolahan citra, deep learning, Faster $R$ CNN, FRCNN;

\section{Pendahuluan}

Surplus Pala diproyeksikan terus meningkat hingga mencapai 39.854 ton pada Tahun 2020. Tingginya produksi Pala Indonesia menempatkan Indonesia sebagai salah satu negara produsen serta eksportir Pala di dunia [1]. Pala memiliki peranan yang signifikan dalam menunjang perdagangan tradisional dan internasional karena menyediakan $75 \%$ kebutuhan pangsa pasar dunia [2]. Indonesia merupakan negara pengekspor terbesar produk pala di Uni Eropa Jika dilihat dari penguasaan pasar, market share pala dan bunga pala utuh sebesar $63,42 \%$ dan $77,74 \%$ sedangkan market share pala dan bunga pala olahan sebesar $34,87 \%$ dan $47,75 \%$ [3]. 
Kabupaten Fakfak merupakan salah satu daerah penghasil pala utama di Provinsi Papua Barat [4]. Luas area tanaman pala di Kabupaten Fakfak mencapai $17.452 \mathrm{Km}^{2}$ (58 persen dari total luas area tanaman pala di Provinsi Papua Barat) dengan produksi mencapai 1.884 ton (11 persen dari total produksi pala Indonesia[5]. Selain sebagai rempah dan bumbu dapur, pala juga dikenal dengan tanaman ekonomis dan multiguna. Setiap bagian tanaman mulai dari daging, biji hingga tempurung dapat dimanfaatkan untuk industry makanan, minuman maupun kosmetik.

Meskipun pala menjadi komuditas unggulan di bidang perkebunan. Namun usaha produksi disektor ini masih memiliki banyak kekurangan dari pra dan pasca proses salah satunya selain factor budidaya dengan belum menggunakan bibit yang unggul, faktor hama, factor umur tanaman juga pengelolaan hasil setelah panen. Tingginya permintaan ekspor biji pala tidak dapat dimaksimalkan disisi petani maupun tengkulak/pengepul dikarenakan proses yang selama ini dilakukan untuk mensortasi biji buah pala masih dilakukan dengan memanfaatkan pengetahuan alamiah (otodidak) dan pengalaman petani dalam memilah dan memilih biji, hal ini sangat tidak efisien dilihat dari segi waktu dan tenaga. hal ini menyebabkan kesalahan sortasi yang berakibat pada nilai jual biji pala menjadi turun.

Kualitas sebuah produk dapat dilihat dari beberapa variabel. Variabel-variabel yang memberi pengaruh terhadap kualitas adalah variabel warna dan bentuk. Kedua variable ini digunakan sebagai salah satu parameter yang paling diperhatikan dalam pemilihan sebuah produk.

Untuk menangani permasalahan tersebut Penelitian dengan tujuan memisahkan biji pala dengan kelas label telah banyak dilakukan dengan teknologi pengolahan citra yang dikombinasi dengan berbagai macam metode klasifikasi. pada percobaan sebelumnya kami menggunakan Convolutional Neural Network (CNN) sebagai algoritma pengklasifikasiannya. Penggunaan variabel warna dan bentuk dengan 8 layer 1 stride, dengan model valisasi $\mathrm{k}$-fold didapatkan akurasi $87 \%$. Pada penelitian lanjutan ini kami tetap mencoba metode deep learning untuk klasifikasi dengan memilih arsitektur Faster R-CNN karena dikenal cukup handal untuk penanganan untuk jumlah data yang banyak. Beberapa penelitian terkait untuk mendeteksi buah menggunakan pengolahan cinta untuk menentukan kualitas mutu buah pisang, salak, manga, jeruk, tomat dan buah naga.

Latifah dinar [6] pendugaan klasifikasi buah pala dengan parameter warna dan bentuk, parameter warna yang digunakan terdiri dari model RGB dipadukan dengan nilai Hue Saturatuion berdasarkan analisis diskriminan menghasilkan akurasi $100 \%$. Susovan Jana [7] melakukan preprocessing gambar dengan segmentasi citra, ekstraksi fitur, representasi fitur dan klasifikasi menggunakan Support Vector Machine (SVM). Pada proses preprocessing gambar, Gambar tersebut diolah untuk memisahkan buah tampak latar depan dan tampak latar belakang.

Candra sekhar [8] juga merancang sebuah sistem yang mendeteksi tingkat kematangan pada buah mangga. Prediksi tingkat kematangan buah dilakukan dengan memanfaatkan video yang dikumpulkan oleh kamera Charge Coupled Device (CCD) pada conveyor yang membawa mangga. Metode yang digunakan pada penelitian ini adalah mengumpulkan gambar dari berbagai macam varietas mangga sebanyak 16400 gambar. Lima varietas mangga dikumpulkan dari tiga lokasi yang berbeda dan dalam tiga kelompok yang berbeda. Kemudian dilakukan teknik eliminasi fitur rekursif yang dikombinasikan dengan klasifikasi berbasis support vector machine (SVM) untuk mengidentifikasi fitur yang paling relevan[9]. Selanjutnya diklasifikasikan menjadi empat kelas berbeda sesuai tingkat kematangannya. Pada proses klasifikasi ensemble dari tujuh klasifikasi biner SVM telah digabungkan untuk mengoreksi kode output sehingga pengambilan keputusan dapat dilakukan menggunakan metode hamming distance-based menghasilkan akurasi 96\%.

Rismiyati [10] mengklasifikan mutu buah salak, Preprocessing dilakukan dengan memotong wilayah bunga (ROI) hanya mengandung gambar salak. Klasifikasi dilakukan dengan menggunakan CNN. Pengujian dilakukan digunakan dua jenis model, model 2 kelas dan model 4 kelas. Hasil percobaan menunjukkan bahwa akurasi terbaik yang diperoleh untuk model 2-kelas adalah $81,45 \%$ dengan menggunakan tingkat pembelajaran 0,0001 , satu lapisan konvolusi dengan lima belas filter dan 100 neuron dalam tersembunyi lapisan. Ukuran filter adalah $3 \times 3 \times 3$. 
Sedangkan model 4 kelas didapat akurasi terbaik 70,71\% dengan dua lapisan konvolusional. jumlah filter di setiap lapisan adalah 6 filter dengan ukuran $3 \times 5 \times 5$ di lapisan pertama dan 18 filter dengan ukuran $6 \times 3 \times 3$ dilapisan kedua.

\section{Metode Penelitian}

Pada Penelitian ini kami menggunakan metode CNN terdiri dari beberapa tahapan proses yaitu : Pengumpulan Data, Preprocessing, Tahap Pelatihan, dan dan Tahap Pengujian serta tahap Validasi .

\section{A. Pengumpulan Data}

Pengumpulan data dilakukan dengan mengumpulkan sampel buah pala yang didapatkan dari tengkulak atau pengepul kemudian dilakukan sortasi warna berdasarkan pengamatan langsung sesuai dengan petunjuk manual mutu kementrian perindustrian.selanjutnya pala yang telah disortasi Langkah ini dilakukan untuk menentukan data biji pala dalam kondisi baik sesuai standar mutu yang ditentukan oleh pemerintah terkait.

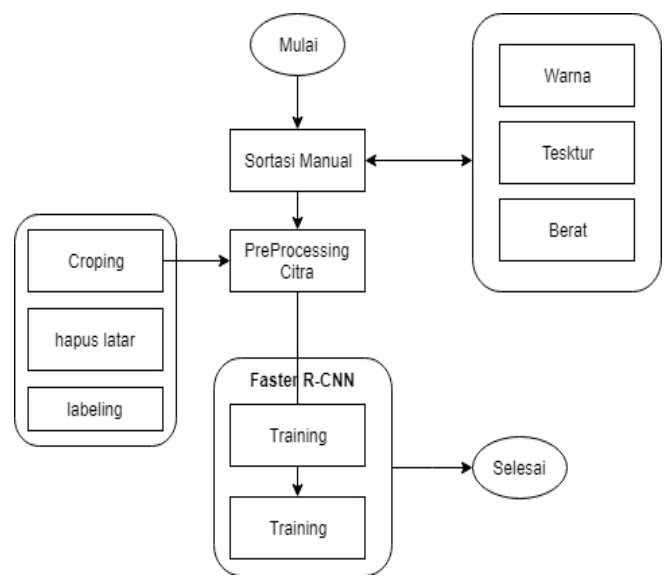

Gambar 1. Diagram Proses Klasfikasi

Gambar 1. Menunjukkan tahapan penelitian dimulai dari pengumpulan data, sortasi berdasarkan standar SNI 0006:2015 terkait dengan mutu pala [11], Prerocessing gambar yang meliputi crop, labeling, sampai pada proses klasifikasi.
Tabel 1. Karakteristik Mutu pala berdasarkan standar SNI

\begin{tabular}{|c|c|c|c|c|c|}
\hline \multirow{2}{*}{ No. } & \multirow{2}{*}{$\begin{array}{l}\text { Kelas } \\
\text { Mutu }\end{array}$} & \multirow{2}{*}{$\begin{array}{c}\text { Kadar } \\
\text { Air }\end{array}$} & \multicolumn{2}{|c|}{$\begin{array}{l}\text { Berat Rata- } \\
\text { rata (gram) }\end{array}$} & \multirow{2}{*}{ Karakteristik } \\
\hline & & & Min & $\max$ & \\
\hline 1 & Mutu 1 & 10.54 & 6.95 & 8.33 & $\begin{array}{l}\text { Biji terpisah dari } \\
\text { fuli, Biji relative } \\
\text { berat, bentuknya } \\
\text { sempurna tidak } \\
\text { keriput, tidak } \\
\text { diserang penyakit, } \\
\text { berjamur }\end{array}$ \\
\hline 2 & Mutu 2 & 8.64 & 5.00 & 6.94 & $\begin{array}{l}\text { Biji relative berat, } \\
\text { berkeriput, tidak } \\
\text { pecah, tidak } \\
\text { terkena penyakit } \\
\text { jamur }\end{array}$ \\
\hline 3 & Mutu 3 & 11.92 & 4.071 & 4.98 & $\begin{array}{l}\text { Biji ringan, } \\
\text { Berkeriput, ada } \\
\text { kerusakan } \\
\text { mekanis, berjamur } \\
\text { atau terserang } \\
\text { penyakit }\end{array}$ \\
\hline
\end{tabular}

Berdasarkan karakteristik tersebut diatas kemudian dilakukan sortasi berdasarkan warna, maka terpilih beberapa warna berikut ini :

(a)

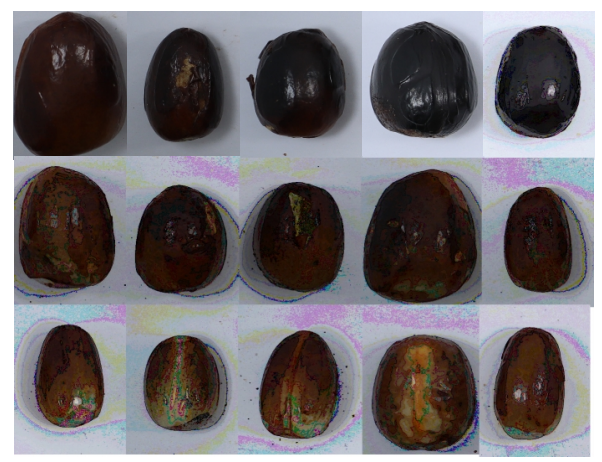

Gambar 1. (a) mutu 1 (b) mutu 2 (c) mutu 3

Sampel biji pala yang telah di sortasi berdasarkan kriteria dari BSN selanjutnya dilakukan pengambilan gambar menggunakan camera canon DSLR1100, terkoleksi masing-masing sebanyak total 3000 gambar untuk biji pala kelas 1, 2, dan 3 .

\section{B. Preprocessing Citra}

Setelah gambar diperoleh dari proses sortasi, langkah selanjutnya adalah melakukan preprocessing untuk 
mempersiapkan gambar untuk proses klasifikasi. Tujuan preprocessing adalah dengan melakukan segmentasi, perubahan ukuran gambar pala. Preprocessing dilakukan dengan memotong area yang hanya mengandung biji buah pala. Ini dilakukan dengan melakukan biner segmentasi pada gambar skala abu-abu dan dapatkan koordinat yang pertama dari atas, sisi kanan, sisi kiri, dan bawah gambar. Koordinat akan bertindak sebagai input ke dalam pemotongan atau proses pemotongan gambar asli (warna). Setelah mendapatkan gambar warna yang telah dipotong, ukuran gambar dilakukan untuk buat ukuran gambar 300 x 300 piksel. output dari proses ini akan menjadi Region of Interest (RoI).Kami menggunakan 8 lapisan konvolusi dengan ukuran gambar 300x300 dan jendela filter $3 \times 3$ thread 2 pada setiap filter. Teknik ini adalah penyempurnaan dari arsitektur VGG-16 [12] yang sebelumnya dilatih oleh ImageNet yang kemudian menghasilkan output lapisan yang sepenuhnya terhubung yang berisi kumpulan skor agregat. Kami mengeksekusi ini karena ImageNet memiliki 1000 kelas, dalam arsitektur VGG16 terdiri dari 4096-4096-4096 neuron di lapisan tersembunyi dan 1000 neuron di lapisan keluaran, sedangkan dalam kasus kami, kami memiliki 3 kelas (quality_A, quality_B, quality_C). kami menggunakan tools ImgLabelling untuk melakukan anotasi gambar dengan cara melabel gambar tersebut satu persatu. Adapun bentuk labeling tersebut dapat dilihat pada gambar dibawah ini :

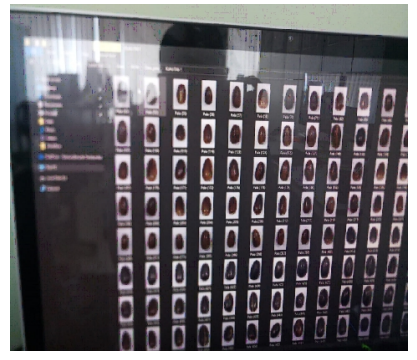

(a)

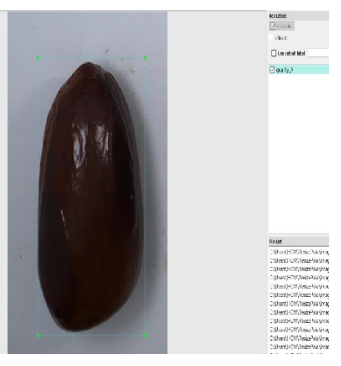

(b)
Gambar 2. (a) Image crop (b)image labeling

Setelah image tersebut dilabel satu persatu, maka data labeling tersebut akan disimpan dalam bentuk file $\mathrm{xml}$. File xml tersebut berisi informasi jarak spasial tetap dari $H \times W \times \mathrm{D}$ (h=height; $\mathrm{w}=$ width, $\mathrm{D}=$ dimention). Ukuran citra dapat dinyatakan sebagai berikut:

\section{$w_{1} x h_{1} x d_{1}$}

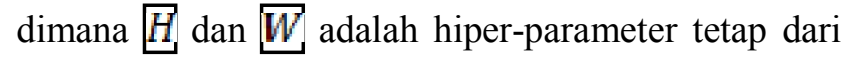
setiap RoI tertentu. Agar memudahkan pengolahan data, isi dari file $\mathrm{xml}$ tersebut di convert menjadi file yang berekstensi .csv sehingga berbentuk tabel:

Tabel 2. Label training

\begin{tabular}{|c|c|c|c|c|c|c|c|}
\hline $\begin{array}{c}\text { Nama } \\
\text { File }\end{array}$ & L & $T$ & mutu & xmin & ymin & xmax & ymax \\
\hline $\begin{array}{c}\text { Pala(001) } \\
\text {.jpg }\end{array}$ & 300 & 500 & $\begin{array}{c}\text { Qualit } \\
\text { y_A }\end{array}$ & 51 & 64 & 261 & 440 \\
\hline $\begin{array}{c}\text { Pala(002) } \\
\text {.jpg }\end{array}$ & 300 & 500 & $\begin{array}{c}\text { Qualit } \\
\text { y_A }\end{array}$ & 35 & 68 & 262 & 468 \\
\hline $\begin{array}{c}\text { Pala(003) } \\
\text {.jpg }\end{array}$ & 300 & 500 & $\begin{array}{c}\text { Qualit } \\
\text { y_B }\end{array}$ & 26 & 60 & 271 & 456 \\
\hline $\begin{array}{c}\text { Pala(004) } \\
\text {.jpg }\end{array}$ & 300 & 500 & $\begin{array}{c}\text { Qualit } \\
\text { y_C }\end{array}$ & 48 & 76 & 247 & 445 \\
\hline$\ldots$ & & & & & & \\
\hline
\end{tabular}

L : lebar image, T: tinggi image

\section{Tahap Pelatihan}

Klasifikasi diterapkan secara langsung dari proses antara data latih dan data uji. Klasifikasi sangat dekat hubungannya dengan prediksi dimana metode ini membangun sebuah model yang disebut model prediktif yang dapat melakukan pemetaan disetiap set variable dengan kelas target, lalu kemudian menggunakan model tersebut untuk memberikan nilai target pada dataset yang baru diperoleh. Model klasifikasi terdiri 2 fase (1) Fase Training : sebuah model dibangun dari data latih. (2). Fase testing : sebuah model digunakan untuk menetapkan label pada sebuah data uji yang tidak berlabel. Pada penelitian ini proses pelatihan di tunjukkan pada Gambar 3. Ada proses feedforward dan backpropagasi dalam tahap ini. 


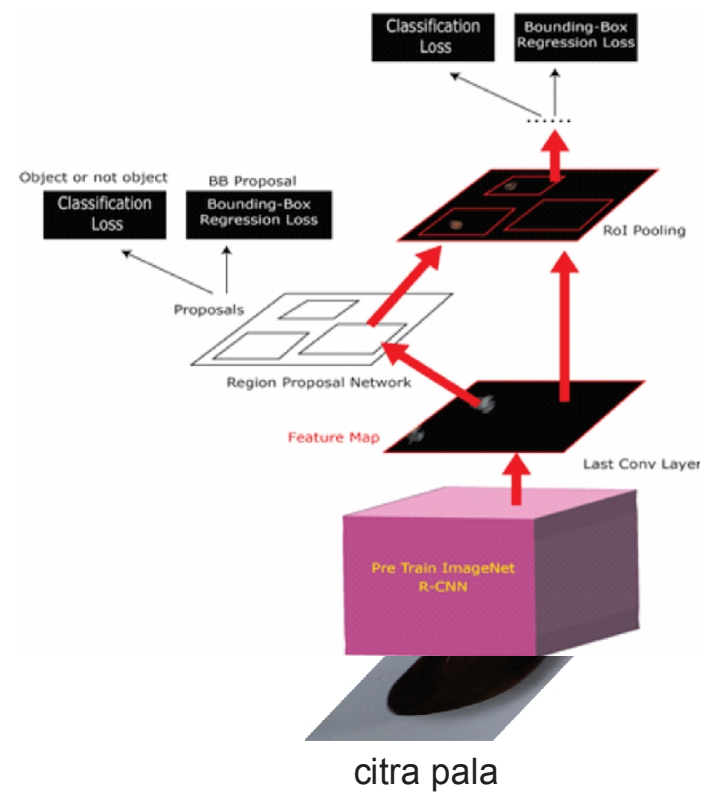

Gambar 3. Arsitektur Faster R-CNN

Pada data pelatihan kami melakukan share_range, zoom dan flip sedangkan parameter rescale pada kasus ini kami gunakan untuk membagi nilai RGB dari 0-255 dengan 255 sehingga mendapatkan nilai RGB pada rentang 0-1. Pada data testing kami hanya melakukan rescale saja. Method flow_from_dyrectory dari ImageGenerator digunakan untuk mengubah data yang berupa "raw image" (data yang telah diaugmentasi) menjadi sebuah dataset yang akan digunakan untuk melakukan proses latih dan testing

\section{Tahap Pengujian}

Proses testing adalah proses utama pada Implementasi metode untuk mengidentifikasi atau mengklasifikasikan jenis mutu buah pala berdasarkan bentuk biji. Klasifikasi mutu Pada Biji pala Berdasarkan Bentuk Biji Menggunakan Metode Faster R-CNN. Proses ini dilakukan untuk menguji sebuah biji pala. Input berupa citra biji pala. Langkah pertama adalah image processing. Image processing adalah prosesproses yang diperlukan sebelum masuk ke dalam proses pengklasifikasian. Dari proses-proses ini akan didapatkan output berupa citra yang memiliki informasi. Informasi yang diberikan adalah jenis mutu biji buah pala. Fungsi Aktivasi yang digunakan adalah momentoptimiser. Dimana fungsi aktivasi yang dipakai harus memenuhi beberapa syarat yaitu : kontinu, terdeferensial dengan mudah dan merupakan fungsi yang tidak turun.

\section{E. Matrik Evaluasi}

Evaluasi performa dari metode klasifikasi dapat menggunakan parameter yang dikenal dengan performance metric yang terdiri dari TP, FP, FN, dan TN. Pada Tabel 3 berikut ini menjelaskan keempat metrik tersebut berdasarkan pada actual label dan predicted label [14]:

Tabel 3. Metrik Performa

\begin{tabular}{|c|c|c|c|}
\hline \multicolumn{2}{|c|}{ Matriks Performa } & Positive & Negative \\
\cline { 2 - 4 } & Positif & True Positif (TP) & $\begin{array}{c}\text { False } \\
\text { Negative(FN) }\end{array}$ \\
\hline \multirow{4}{*}{$\begin{array}{c}\text { Actual } \\
\text { Label }\end{array}$} & Negatif & $\begin{array}{c}\text { False Positif } \\
\text { (FP) }\end{array}$ & $\begin{array}{c}\text { True } \\
\text { Negative } \\
\text { (TN) }\end{array}$ \\
\hline
\end{tabular}

Ukuran metode klasifikasi:

1. Accuracy atau tingkat pengenalan menyatakan persentase dari jumlah tupel dalam data uji yang diklasifikasikan dengan benar oleh model klasifikasi. Accuracy dapat dituliskan dengan formula :

$$
\begin{array}{|c|}
T P+T N \\
\hline P+N \\
\hline
\end{array}
$$

Dimana : TP : True Positive, TN : True Negatives, $\mathrm{P}:$ Positive, $\mathrm{N}$ : Negatives

2. Precision atau kepastian adalah persentase tuple positif yang dilabeli benar pada kenyataannya, dapat dituliskan dengan formula :

$$
\begin{array}{|c|}
\hline T P \\
\hline T P+F P
\end{array}
$$

3. Recall adalah ukuran kelengkapan, yaitu berapa persentase tuple positif yang dilabeli dengan tuple positif. Recall dapat dituliskan dengan formula :

$$
\frac{T P}{T P+F P}=\frac{T P}{P}
$$




\section{Hasil dan Pembahasan}

Percobaan dibuat dengan dua scenario untuk mengevaluasi hasil pelatihan (training) dan keakuratan deteksi penentuan mutu citra biji pala.

\section{A. Skenario Percobaan}

untuk menguji keakuratan atau kevalidan metode dibuat tiga skenario percobaan yaitu : percobaan 1 (satu) kami mencoba menggunakan pendekatan algoritma deep learning dengan menggunakan arsitektur $\mathrm{CNN}$, proses pertama dilakukan sama seperti pengolahan citra pada umumnya yaitu dengan melakukan sortasi manual yang didasarkan pada standar SNI 0006:2015 tentang pala, selajutnya pengambilan gambar (image), preprocessing image: crop, resize, reduce background dan selanjutnya proses klasifikasi dengan menggunakan 8 layer, 1 stride , ukuran image $300 \times 500$ piksel. Jumlah data masingmasing kelas sebanyak 1000 dataset. dengan metode flip image. Pada scenario percobaan pertama, data latih dilakukan dengan 1000 kali pengulangan dengan learning rate 0.0001. Gambar 4. (a) dengan epoch 1000 didapatkan hasil akurasi $87 \%$.

Percobaan 2: Gambar 4. (b) menunjukkan grafik ROC yang didapatkan menggunakan metode Faster RCNN. Hasil latih yang dilakukan dengan menggunakan 10000 iterasi mendapatkan akurasi sebesar 95\% dengan loss sebesar 1,745. Dari grafik ROC menunjukkan tingkat akurasi yang cukup tinggi dengan melakukan optimasi dan memasang learning rate sebesar 0.0001 .

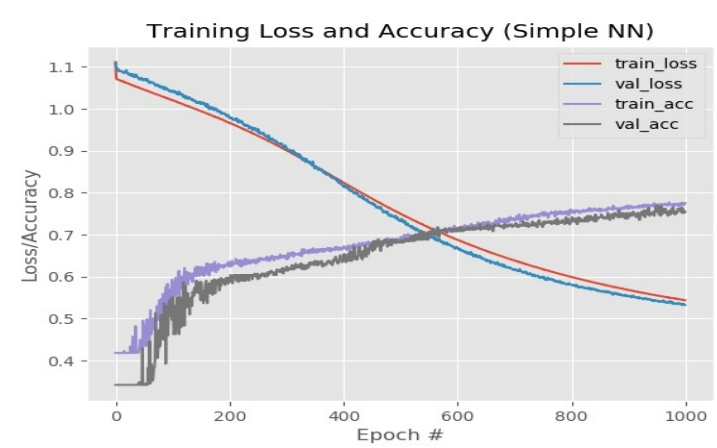

(a)

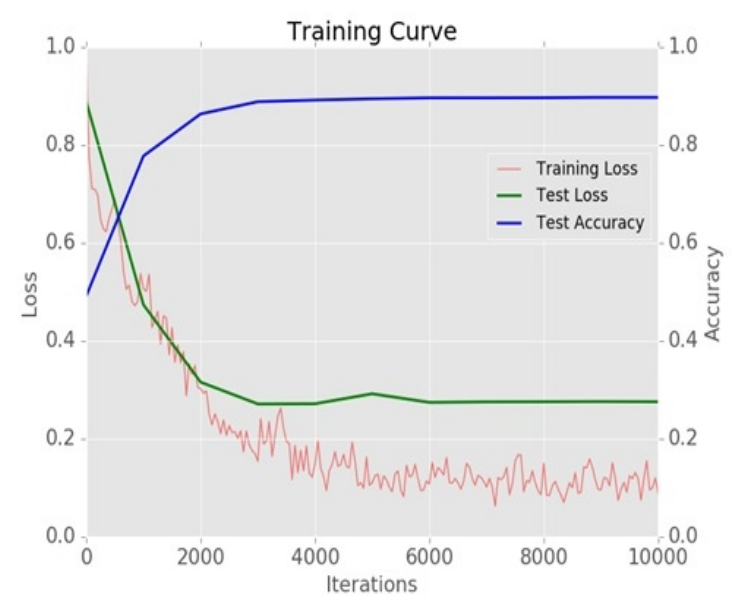

(b)

Gambar 4. (a) Grafik ROC CNN (b) Grafik ROC Faster $\mathrm{R}-\mathrm{CNN}$

Gambar 4. (b) Skenario percobaan ini, dapat disimpulkan bahwa proses ekstraksi fitur sangat berpengaruh pada keakuratan setiap training dan testing. Oleh karena itu, untuk menghasilkan akurasi maksimum, diperlukan pengamatan yang lebih cermat untuk menentukan model yang digunakan dalam ekstraksi fitur. Namun, tidak semua model yang memiliki akurasi yang baik cocok untuk digunakan dalam kasus objek deteksi secara real time. Kami telah menggunakan model ini untuk deteksi objek, tetapi ada banyak objek yang bahkan tidak terdeteksi. Namun, ada juga banyak objek yang terdeteksi salah, misalnya Quality_C bukannya diberi label sebagai Quality_B. dengan menggunakan CNN yang sama yang di improve dengan metode Faster R-CNN membutuhkan waktu pengoperasian yang sangat cepat. Dari pengamatan kami, algoritma ini dapat mendeteksi objek streaming video hingga 5 frame per detik. Berikut ini adalah tabel perbandingan proses komputasi dari beberapa metode yang berbeda.

Tabel 4. Perbandingan beberapa metode klasifikasi

\begin{tabular}{|l|c|}
\hline \multicolumn{1}{|c|}{ Metode } & Waktu proses per gambar \\
\hline $\mathrm{NN}$ & 1 detik \\
\hline $\mathrm{CNN}$ & 0,6 detik \\
\hline RCNN & 0,2 detik \\
\hline Faster R-CNN & 0,024 detik \\
\hline
\end{tabular}




\section{B. Hasil Pengujian}

Proses validasi menggunakan 1000 data untuk menguji jaringan dengan masing-masing kelas 300 sampel data ini tidak diikutkan dalam training. Dari proses ini didapatkan akurasi terbaik yaitu $95 \%$ dengan jumlah data yang benar sebanyak 950 dengan waktu proses 0.04 time/second. Gambar 4 disajikan matriks confusion dari data validasi.

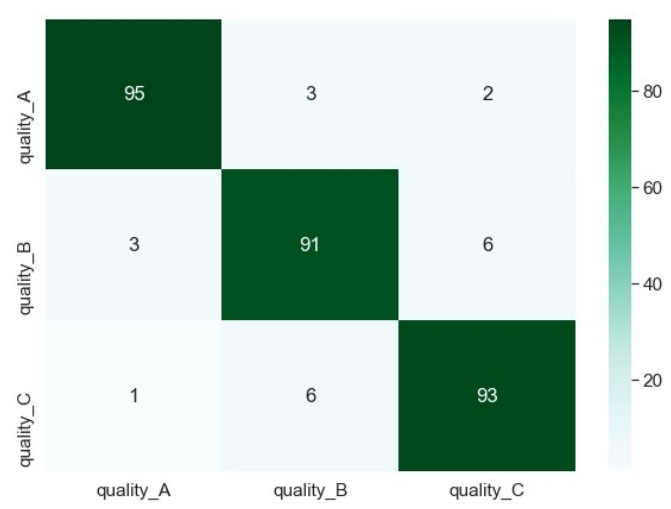

Gambar 4. Matriks confusion dari data validasi

Tabel 5. Pengukuran Performance CNN

\begin{tabular}{|c|c|c|c|}
\hline Class & Precision & Recall & F1-Score \\
\hline Quality_A & 0.86 & 0.73 & 0.79 \\
\hline Quality_B & 0.50 & 0.95 & 0.66 \\
\hline Quality_C & 0.51 & 0.24 & 0.32 \\
\hline
\end{tabular}

Tabel 6. Pengukuran Performance Faster R-CNN

\begin{tabular}{|c|c|c|c|}
\hline Class & Precision & Recall & F1-Score \\
\hline Quality_A & 0.95 & 0.84 & 0.89 \\
\hline Quality_B & 0.72 & 0.62 & 0.67 \\
\hline Quality_C & 0.63 & 0.77 & 0.69 \\
\hline
\end{tabular}

Percobaan (3) : Pelacakan Video

Tabel 7. Hasil Prediksi menggunakan video

\begin{tabular}{|l|c|l|l|}
\hline No. & Hasil Deteksi & Label Aktual & Label Prediksi \\
\hline 1. & Quality_A & Quality_A \\
\hline
\end{tabular}

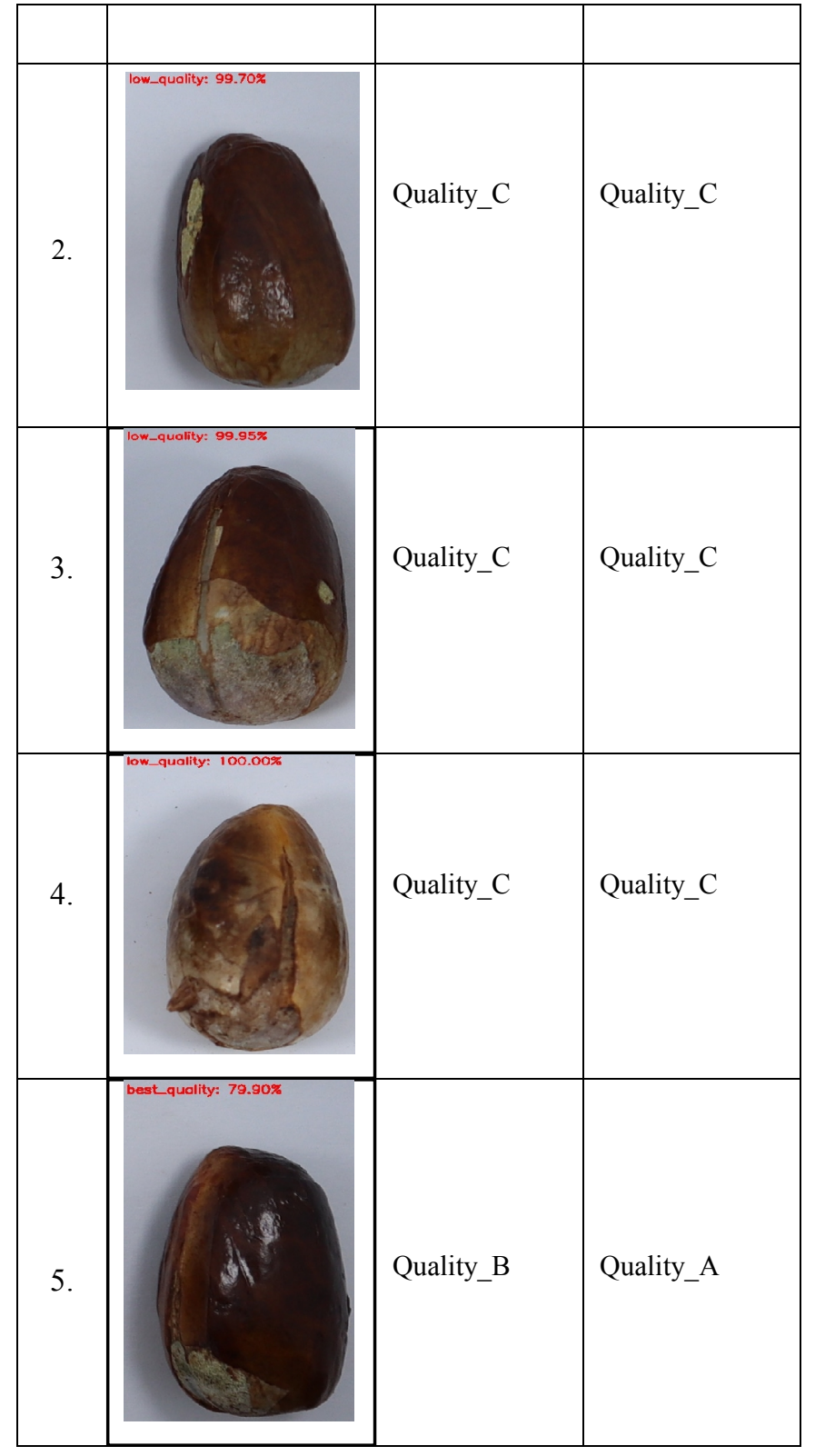

Tabel 7. menunjukkan hasil capture gambar percobaan kami dalam melakukan proses deteksi biji buah pala secara real time. Dari hasil di atas, kami menyimpulkan proses untuk deteksi objek sangat konstan, tetapi masih ada kekurangan. Yaitu ketika biji buah pala dimasukkan tiga kelas jenis buah secara bersamaan, ada beberapa biji buah pala yang diprediksi tidak sesuai dengan kelas labelnya. Metode Faster RCNN menawarkan solusi untuk menyelesaikan kasus deteksi kualitas buah secara real time yang mampu mengelola banyak kelas. Dalam penelitian kami di masa depan, kami bertujuan untuk memodifikasi arsitektur 
pada ekstraksi fitur, sehingga menjadi mampu menghasilkan model terbaik dan meminimalkan kesalahan dalam deteksi kualitas buah.

\section{Kesimpulan}

Tulisan ini menyajikan sistem yang mengklasifikasikan buah dengan tingkat akurasi 95\% (Quality_A), 91\% (Quality_B), 93\% (Quality_C) dan dengan waktu pemrosesan rata-rata 0,04 menit per detik.jauh lebih baik dari percobaan dengan metode Deep learning dengan arsitektur CNN yang hanya mendapatkan hasil akurasi terbaik sebesar $86 \%$. Kumpulan data diambil di tingkat petani dan pengepul (tengkulak) kemudian dilatih menggunakan Faster RCNN. Lebih cepat dari metode CNN dengan prinsip yang sama dan menunjukkan hasil yang luar biasa pada awal revolusi pembelajaran yang mendalam. Algoritma ini memberikan solusi untuk menyelesaikan kasus deteksi kualitas buah secara real time menggunakan multi-kelas. Dalam penelitian lebih lanjut, kami perlu melakukan percobaan untuk dapat melacak dan menghitung buah yang cacat secara straming yang dapatt diterapkan pada conveyot yang berjalan sehingga memudahkan pihak tengkulak (pengepul) dalam sortasi biji pala yang selama ini dlakukan dengan manuak

\section{Ucapan Terima Kasih}

Ucapan terima kasih diberikan kepada Kementrian Riset Teknologi Pendidikan Tinggi atas bantuan Pendanaan Penelitian Dosen Pemula (PDP) Tahun 2019.

\section{Daftar Pustaka}

[1] Pusat Data dan Sistem Informasi, Outlook Pala 2016. Pusat Sekretariat Jenderal Kementerian Pertanian, 2016.

[2] Direktorat Jendral Perkebunan. (2012). Statistik perkebunan Indonesia. Pala. Jakarta. Direktorat Jendral Produksi Perkebunan.

[3] J. Hadiyanto and S. Suminto, "DAYA SAING PRODUK PALA INDONESIA DI PASAR UNI EROPA The Competitiveness Level of Indonesian Nutmeg In European Union Market," no. September 2018, 2017.

[4] Fakfak, B. K. (2017) Fakfak Dalam Angka (Fakfak Regency in Figures) 2017. doi:10.15713/ins.mmj.3.

[5] UNDP (2013) 'Kajian Pala dengan Pendekatan Rantai Nilai dan Iklim Usaha di Kabupaten Fak-fak', p. 42.

[6] Ratna Wylis Arief, F. A. dan R. A. (2015) 'BERNILAI EKONOMI TINGGI Potential of nutmeg fruit processing being various products with high value economic', pp. 165-174

[7] Dinar, L., Suyantohadi, A. and Falah, M. A. F. (2012) 'Pendugaan Kelas Mutu Berdasarkan Analisa Warna Dan Bentuk Biji Pala ( Myristica fragrans houtt ) Menggunakan Teknologi Pengolahan Citra Dan Jaringan Saraf Tiruan', Jtep, 26(1), pp. 53-59

[8] S. Jana and S. Basak, "Automatic Fruit Recognition from Natural Images using Color and Texture Features," pp. 23-24, 2017.

[9] C. S. Nandi, B. Tudu, and C. Koley, "A machine vision-based maturity prediction system for sorting of harvested mangoes," IEEE Trans. Instrum. Meas., vol. 63, no. 7, pp. 1722-1730, 2014..

[10] S. Basak, "An Improved Bag-of-Features Approach for Object Recognition from Natural Images," vol. 151, no. 10, pp. 5-11, 2016.

[11] I. S. Sortation, "Convolutional Neural Network Implementation for," 2016.

[12] Dahlia Rara Rosyali (2016) 'Identifikasi Sifat Fisik, Mekanik dn Morfologi Buah Pala (Myristica fragrans Houtt) Dari Desa Batu Kramat Kecamatan Kota Agung Kabupaten Tanggamus selama Penyimpanan.

[13] K. Simonyan and A. Zisserman, "Very Deep Convolutional Networks for Large-Scale Image Recognition," arXiv Technical Report, 2014. [Online]. Available: https://arxiv.org/abs/1409.1556. [Accessed: 14-Feb-2019]

[14] Tresna Maulana Fahrudin, Iwan Syarif, Ali Ridho Barakbah, Ant Colony Algorithm for Feature Selection on Microarray Datasets, The co-sponsored IEEE International Electronics Symposium (IES), 2016, September 29-30, 2016, Bali, Indonesia. 